\title{
Automatic feeders for Nile tilapia raised in cages: productive performance at high feeding frequencies and different rates
}

\author{
[Alimentadores automáticos para tilápia-do-nilo criadas em tanques-rede: desempenho \\ produtivo com alta frequência alimentar e diferentes taxas de alimentação] \\ F.A. Oliveira ${ }^{1}$, D. Argentim ${ }^{1}$, P.K. Novelli ${ }^{1}$, S.M.M. Agostinho ${ }^{2}$, L.M. Agostinho ${ }^{1}$, \\ C.A. Agostinho ${ }^{3}$ \\ ${ }^{1}$ Aluno de pós-graduação - FMVZ-Universidade Estadual Paulista "Julio de \\ Mesquita Filho" - Botucatu, SP \\ ${ }^{2}$ Cuesta Aquicultura - Botucatu, SP \\ ${ }^{3}$ FMVZ - Universidade Estadual Paulista "Julio de Mesquita Filho"- Botucatu, SP
}

\begin{abstract}
The main goal of modern intensive fish farms should be to increase productivity at a low cost. The automation of fish feeding plays an important role in this scenario since it may improve feed efficiency and reduce organic waste emissions. The aim of this experiment was to provide basic information for the development of feeding techniques using automatic feeders. The experiment was done from September to December, with tilapia weighing $185 \mathrm{~g}$, fed 48 meals a day at 22 or 30 minute intervals, with feeding rates of 2, 3 and $4 \%$ of live weight. Eighteen $1 \mathrm{~m}^{3}$ net cages equipped with automatic feeders were distributed in one pond. During the experimental trial the mean values for dissolved oxygen, $\mathrm{pH}$ and temperature were $3.20 \mathrm{mg} / \mathrm{l}, 8.03$ and $25.43^{\circ} \mathrm{C}$, respectively. The highest average weight of $683.73 \mathrm{~g}$ was achieved for fish treated with $4 \%$ of live weight at 30 minute intervals between meals. There was no difference for viscero-somatic index, demonstrating no alteration in the final carcass quality. These results demonstrate that a higher feeding rate added to efficient feed management can be used at the final stages of raising Nile tilapia in cages without compromising final fish productive quality.
\end{abstract}

Keywords: automatic feeding; feeding management; Oreochromis niloticus; feed efficiency; carcass indexes

\section{RESUMO}

O principal objetivo da criação intensiva de peixes deve ser o aumento da produtividade com baixos custos. Automação da alimentação tem papel importante nesse cenário, uma vez que melhora a eficiência alimentar e reduz a emissão de lixo orgânico. O objetivo deste experimento foi produzir informação básica para o desenvolvimento de tecnologia alimentar mediante o uso de alimentadores automáticos. $O$ experimento foi realizado de setembro a dezembro, com tilápias pesando $185 \mathrm{~g}$ e alimentadas 48 vezes ao dia, em intervalos de 22 ou 30 minutos, com taxa de alimentação de 2, 3 e 4\% do peso vivo. Dezoito tanques-rede de $1 \mathrm{~m}^{3}$ foram equipados com alimentadores automáticos e distribuídos em um lago. Durante o experimento, a média de oxigênio dissolvido, a de $\mathrm{pH}$ e a de temperatura foram 3,20mg/L, 8.03 e $25,43^{\circ} \mathrm{C}$, respectivamente. A maior média de peso de $683,73 \mathrm{~g}$ foi obtida para os peixes tratados com $4 \%$ do peso vivo e intervalo de 30 minutos entre as refeições. Não houve diferença no índice víscerosomático, o que demonstra a mesma qualidade final da carcaça. Esses resultados mostram que a alta taxa de alimentação, associada ao eficiente manejo alimentar, pode ser usada nos estágios finais de produção de tilápia-do-nilo em tanques-rede, sem comprometer a qualidade do produto final.

Palavras-chave: alimentação automática, manejo alimentar, Oreochromis niloticus, eficiência alimentar, índices de carcaça

Recebido em 3 de agosto de 2014

Aceito em 22 de dezembro de 2015

* Autor para correspondência (corresponding author)

E-mail: pnovelli@hotmail.com 


\section{INTRODUCTION}

In the last decade, Tilapia has become the most cultivated fish in Brazil. Several species and hybrids of the Oreochromis genus are responsible for about $40 \%$ of the total aquaculture production in the country. It is estimated that the tilapia production has increased $105 \%$ from 2003 to 2009 , reaching from 65 thousand tons to 133 thousand tons. (Brasil, 2010). Up to $200 \mathrm{~kg} . \mathrm{m}^{-3}$ can be achieved in intensive and super intensive tilapia cultivation farms under ideal conditions. Mistakes in feeding management can cause produce and performance economic losses in high density systems (Conte et al., 2008).

The productive performance of fish farming depends on the species, sex, stage of development and feeding management ( $\mathrm{Ng}$ et al., 2000; Mihelakakis et al., 2002; Zuanon et al., 2004; Chagas et al., 2005). Moreover, management involves a number of meals, time of feed offer and feeding rate. The rate depends on density, dissolved oxygen, water quality and temperature.

According Barbosa et al., (2005), the basic fish needs cannot be met with low feeding rates, while high levels can increase the speed of feed passage through the digestive tract, affecting feed utilization. Sousa et al. (2012) evaluated the performance of tilapia fed 6,12 and 24 meals a day during daytime, night, and day/night, and they found better performance in fish fed 24 meals a day. This result led the authors to suggest the possibility of increasing feed rate to higher levels than those found in literature and still reaches good feed utilization, since the daily amount of feed was provided in several meals per day.

Tilapia has a small amount of fat between the muscle fibers. However, other parts of the carcass have considerable fat depositions, especially visceral tissues, which are thrown away by slaughterhouses. The increase of such waste has led the seafood industry to search for other solutions, from the economic point of view and for consumer health (Airua and Carvalho, 2004). Fat is the main form of body energy storage (Meurer et al., 2002). One way to measure this accumulation is the liposomatic index. High feed frequency coupled with increase in feed rate can cause higher liposomatic rates (Cho, 2003). In addition, the greatest weight gain may result in fat accumulation and not mass increase. Thus, liposomatic index is an important tool to prevent slaughter wastes.

The aim of this study was to evaluate tilapia performance fed with a high number of meals a day at different rates and feeding times in the final growing stage.

\section{MATERIAL AND METHODS}

This experiment was conducted from September to December, in eighteen net cages, arranged linearly in one pond of approximately $2000 \mathrm{~m}^{2}$ of water surface, average depth of $2 \mathrm{~m}$, with flow rate of 5 liters per second. The pond could be water supplied by electric pump if necessary. The net cages were $1.0 \mathrm{~m}$ wide, $1.0 \mathrm{~m}$ long and $1.2 \mathrm{~m}$ deep, manufactured with metal mesh $\left(5 / 8^{\prime}\right.$ mesh), covered with "PVC". Polyethylene mesh feeders were attached to the center of the net cage to hold feed waste. Metal support brackets were placed over the net cages to stand the automatic feeders in each center. Automatic feeders (Agostinho et al., 2004) were programmed according to intervals and predefined amounts for each experimental design. They are able to store eight kilograms of feed and they were supplied periodically according to feed consumption.

Feeders were controlled by a central poweroperated panel, installed outside the pond, including timers that handle the mechanism of feed supply. It was possible to handle the amount of food given and the intervals between meals.

Tilapias with $185 \mathrm{~g}$ on average were placed in net cages at density of 93 fish per cubic meter. Feed levels applied were $2 \%, 3 \%$, and $4 \%$ of live weight and 48 meals a day. The experiment was carried out in a factorial design with three feed rates, two feeding intervals and three replicates per treatment; each experimental unit was completely randomized. Feeders remained on for 24 hours in the 30 minute interval treatments; and for the 22 minute interval treatments, the feeders were turned on at eight o'clock in the morning and remained working for 18 hours straight. 
A sample of 20 fish per net cage was individually weighed every fifteen days for analysis of weight gain. After each biometrics and according to the feed level of each treatment, the amount of feed was adjusted. Commercial analyzed ration for tilapia containing 32\% of crude protein, $65 \%$ lipids, $70 \mathrm{~g} \cdot \mathrm{kg}^{-1}$ fiber, $10 \mathrm{~g} \cdot \mathrm{kg}^{-1}$ calcium and $6 \mathrm{~g} \cdot \mathrm{kg}^{-1}$ phosphorous was used for all treatments.

At the end of the experiment, animals were slaughtered and viscera, liver, and adipose tissue were weighed. The calculation of liposomatic, hepatosomatic and viscero-somatic indexes were performed according to methodology described by $\mathrm{Ng}$ et al. (2000), where the index is the result of the weight of the organ or tissue divided by the total weight of the fish. Values were used to evaluate the fish nutritional condition.

Physic-chemical parameters of the water were measured daily. The levels of dissolved oxygen were measured with YSI55 oximeter every day in the morning at 3 different points of the pond. The maximum and minimum temperatures were recorded daily, $\mathrm{pH}$ (using Oakton electrode) was measured in the morning and afternoon. Mean values of dissolved oxygen, $\mathrm{pH}$ and temperature were $3.20 \mathrm{mg} .1^{-1}, 8.03$ and $25.43^{\circ} \mathrm{C}$, respectively.

The experimental design was completely randomized with $3 \times 2$ factorial treatments and three replicates. Weight gain, feed conversion and mortality were the response variables. Data of weight gain and feed conversion were analyzed, including the following effects in the model: feed rate, interval between feeding, and the interaction among them. Means were compared by Tukey test $(\mathrm{P}<0.05)$. The experiment was approved by the Institution Ethics Committee for Animal Use (CEUA) under the protocol number 108206-CEEA.

\section{RESULTS AND DISCUSSION}

Performance results obtained during the experiment are shown in Table 1. Leftovers were not collected because this experiment was carried out in a pond; therefore, the calculated feed conversion rate was apparent. The final weight, feed intake, daily and total weight gain, and production yield increased for higher feed level, regardless the feeding period. Treatment with higher feed rate showed the greatest weight gain, although feed conversion rate was worse than for the other treatments (Table 1). According Riche, (2004), when feed is supplied at intervals shorter than the time required for appetite return, gastric overload may occur, resulting in reduced absorption efficiency. In this study, the daily amount of feed was based on body weight $(2 \%$, $3 \%$ or $4 \%$ ) fractionated in several meals a day. This management may have reduced the gastric overload, contributing to a better use of the feed.

Table 1. Performance parameters for Nile tilapia raised in cages during 120 days fed with different feeding intervals (22 min and $30 \mathrm{~min})$ and feed rates $(2 \%, 3 \%$ and $4 \%)$

\begin{tabular}{cccccccccc}
\hline Treatment & $\begin{array}{c}\text { IW } \\
(\mathrm{g})\end{array}$ & $\begin{array}{c}\text { FW } \\
(\mathrm{g})\end{array}$ & AFC & $\begin{array}{c}\mathrm{I} \\
(\mathrm{kg})\end{array}$ & $\begin{array}{c}\mathrm{DG} \\
(\mathrm{g})\end{array}$ & $\begin{array}{c}\text { TG } \\
(\mathrm{g})\end{array}$ & $\begin{array}{c}\mathrm{S} \\
(\%)\end{array}$ & $\begin{array}{c}\mathrm{P} \\
(\mathrm{kg} / \operatorname{tank})\end{array}$ & $\begin{array}{c}\mathrm{Y} \\
(\mathrm{kg} / \mathrm{m} 3)\end{array}$ \\
\hline $22 \min 2 \%$ & $184.54 \pm 40.13$ & $489.82 \pm 95.15$ & 1.73 & 131.28 & 2.53 & 301.15 & 98 & 102.84 & 34.28 \\
$22 \min 3 \%$ & $185.99 \pm 40.32$ & $615.30 \pm 99.91$ & 1.70 & 176.34 & 3.61 & 429.00 & 99 & 129.15 & 43.05 \\
$22 \min 4 \%$ & $187.19 \pm 39.88$ & $681.00 \pm 100.28$ & 1.96 & 274.37 & 4.17 & 495.75 & 95 & 143.01 & 47.67 \\
$30 \min 2 \%$ & $184.21 \pm 40.02$ & $454.38 \pm 102.80$ & 1.67 & 110.80 & 2.31 & 275.02 & 100 & 95.40 & 31.80 \\
$30 \min 3 \%$ & $186.70 \pm 39.72$ & $610.47 \pm 110.61$ & 1.70 & 204.52 & 3.55 & 422.30 & 98 & 128.19 & 42.73 \\
$30 \min 4 \%$ & $191.67 \pm 35.18$ & $683.73 \pm 106.52$ & 1.87 & 225.27 & 4.14 & 492.07 & 98 & 143.58 & 47.86
\end{tabular}

Initial weight (IW), final weight (FW), apparent feed conversion rate (AFC), intake (I), daily gain (DG), total gain (TG), survival (S), production (P) and Yield (Y).

Fish fed with $4 \%$ of live weight per day and 30 minute intervals had better average daily gain $(4.14 \mathrm{~g})$ and feed conversion rate (1.87), although there was no significant difference compared with the feed rate of $4 \%$ and 22 minute interval (Table 1). Similar results were found by Furuya
(1997) with daily gain of $3.46 \mathrm{~g}$ and feed conversion of 2.10 for tilapia fed at a rate of $3.5 \%$ of live weight. In this study, fish were fed during a period of 120 days without changes in feed rate, which differs from the recommendation of Kubitza (2000), who 
suggests the use of feeding tables according to weight range and water temperature. Barbosa et al. (2005), studying different feeding sequences for tilapia with initial weight of $50 \mathrm{~g}$ in 126 days of rearing, found better performance and economic returns for fish fed with initial rate of $5 \%$ (536.5g). Besides, this study showed that fish can reach satisfactory growth with the maintenance of feed rate of $4 \%$.

Fish fed rates of $4 \%$ of live weight at 30 minute meal intervals reached higher weight $(\mathrm{P}<0.05)$. However, there was no interaction between feed level and feeding intervals (Table 2). Moreover, results found in the literature show the benefits of increasing the feeding frequency as uniform lots, better nutrients absorption, and lower leaching losses, therefore better performance (Wang et al., 1998; Zarate and Lovell, 1999; Carvalho and Nunes, 2006). When fish were fed $3 \%$ of live weight, feeding management promoted good results (Table 1), considering an average temperature of $25^{\circ} \mathrm{C}$, with a feed conversion of 1.70 and $424 \mathrm{~g}$ weight gain in 120 days of cultivation. Leanhardt and Urbinati (1999), comparing growth of male sexed and reversed tilapia, with initial weight of $152.57 \mathrm{~g}$, fed $1 \%$ to $3 \%$ of biomass per day, 3-4 times a day, achieved $247.46 \mathrm{~g}$ of weight gain in 98 days of cultivation. The higher weight gain obtained compared to the previously mentioned studies may be due to the high number of meal used in this experiment, which was possible due the automatic feeders. Even with the feed rate of $2 \%$, fish gained more weight (Table 1) compared to Romagosa et al. (2000). These authors fed two batches of Nile tilapia with rates of $3 \%$ and $5 \%$ of live weight in two meals a day for 150 days of cultivation. The best gain achieved was $124.94 \mathrm{~g}$. Most likely, the difference in weight gain between these studies may be attributed to the high feeding frequency, since the author previously mentioned provided feed at low feeding frequency. Moreover, it is clear that the number of meals contributes to better feed utilization, because even using higher feed rates, Romagosa et al. (2000) achieved lower results.

Table 2. Average final weight for different feeding rates and intervals (feeding frequency) for Nile tilapia raised in cages during 120 days

\begin{tabular}{ccccc}
\hline \multicolumn{5}{c}{ Feeding rate } \\
\hline Interval (minutes) & $2 \%$ & $3 \%$ & $4 \%$ & Means \\
22 & $454.38 \pm 102.80$ & $615.30 \pm 99.91$ & $681.00 \pm 100.28$ & $582.86 \mathrm{~ns}$ \\
30 & $489.81 \pm 95.15$ & $610.47 \pm 100.69$ & $683.73 \pm 106.52$ & $595.37 \mathrm{~ns}$ \\
\hline Mean & $472.10 \mathrm{c}$ & $612.88 \mathrm{~b}$ & $682.37 \mathrm{a}$ & \\
\hline
\end{tabular}

Means followed by the same letter do not differ from each other $(\mathrm{P}<0.05)$; ns: no significance

Mean values of $\mathrm{pH}$ and temperature were within the range considered ideal for tilapia, according to Boyd (1982), and Kubitza, 2000. Dissolved oxygen mean was below the minimum considered proper for good productive performance of the fish Boyd (1982); Kubitza, 2000). Even lower values were found during the experiment at night. However, even under these conditions, fish of all treatments showed great performance. One factor that may have contributed to good performance is the number of meals used in this study, as subdivision of the daily ration in small portions may have decreased the demand for oxygen to metabolize each meal.

The survival rate was not influenced by the treatments and remained above 95\% (Tab. 1). These values are considered good and are similar to those found in literature (Ridha, 2006; Nogueira and Rodrigues, 2007).

The feed management tested in this study can also reduce production costs because it increases the amount of available feed with some benefits such as increased performance parameters, such as weight gain and less cultivation time due to the speed in which fish reaches market weight. Moreover, yields increased by $50 \%$ for 30 minute intervals between meals when a higher feed rate was used rather than the lower feed rate. For the feeding frequency of 22 minute interval, the increase was $40 \%$ on average. Moreover, since there was no difference between the tested feeding intervals, fish can be induced to be fed during the night with automatic feeders, even with low dissolved oxygen in the water. 
This study evidenced that the feeding rate did not affect the viscero-somatic index, demonstrating that there was no loss in the carcass as the feed rate was increased. However, significant differences in liposomatic and hepatosomatic indexes were found. The mean values for hepatosomatic (HIS), viscero-somatic (VSI), and liposomatic (LSI) indexes are shown in Table 3. There was no significant difference between treatments related to viscero-somatic indexes. However, there were differences between the hepatosomatic and liposomatic indexes according the feeding rates. The hepato and liposomatic indexes linearly increased as the feed rate increased (Table 3). Such results are similar to those found by $\mathrm{Du}$ et al. (2006), when evaluating the influence of different feeding levels on growth and feed efficiency of juveniles of mirror carp (Cyprinus carp). The authors found significant differences for liposomatic, hepatosomatic and viscero-somatic indexes of the fish as feed rates increased.

Table 3. Means for hepatosomatic index (HSI), liposomatic index (LSI) and viscero-somatic index (VSI) of Nile tilapia grown in cages at different feeding rates and intervals

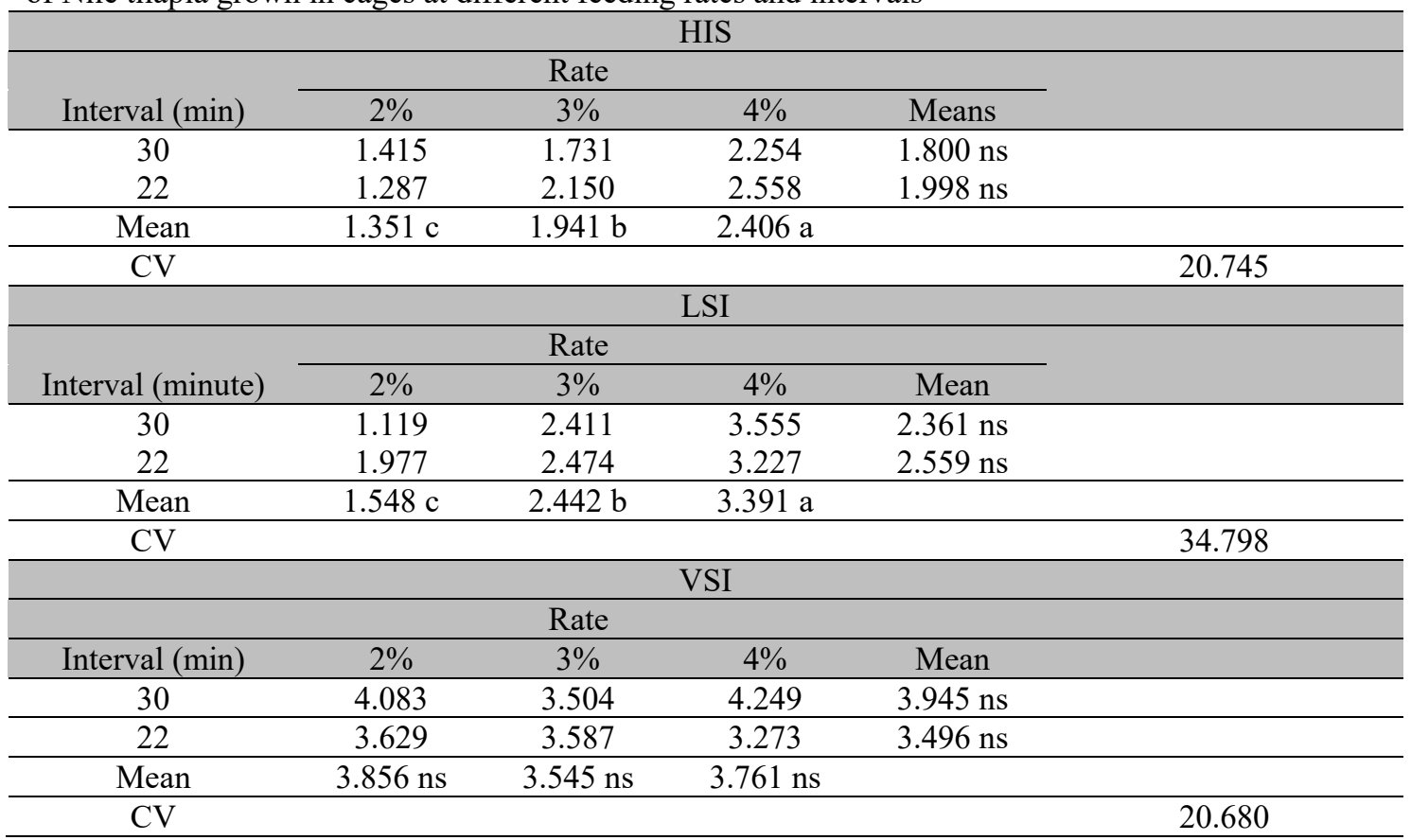

Means followed by the same letter do not differ from each other $(\mathrm{P}<0.05)$; ns: no significance

Tilapia (Oreochromis shiranus) fed diet containing $30 \%$ crude protein and four different levels of energy, using a feed rate of $4 \%$ of live weight, had significant differences for hepatosomatic index, showing a $2.58 \%$ index when tilapia were fed with a diet containing $4,895 \mathrm{kcal}_{\text {.gram }}{ }^{-1}$ of energy (Kang'ombe et al., 2007), these results confirm the numbers found in this study (Table 3).

Bureau et al. (2006) found that fish fed low feed rates accumulate less body fat; on the other hand, they have lower performance. The same occurred in this study for treatment with $2 \%$ feed rate, where fish had lower levels of body fat (Table 3), resulting in the worst result for weight gain $(275.02 \mathrm{~g})$ in 120 days (Table 1$)$.

The highest feeding rate promoted improvement in the performance of the fish, showing that increasing rates indicates improvement in fish performance $(\mathrm{Ng}$ et al., 2000; Mihelakakis, 2002). The high number of meals, together with the increase in feed rate, may have increased the liposomatic index for the treatment with $4 \%$ of live weight compared to the other treatments (Tab. 3). However, other factors also affect the accumulation of body fat, such as the production stage, the intensity of fish movement in the farming system, food restriction, diet composition and, especially, origin of fatty acids 
used in the diet (Jeong, 2003; Arbeláez-Rojas, 2002; Kiessling, 2005). Therefore, it cannot be stated that this accumulation was due to the feeding management applied.

\section{CONCLUSION}

The high number of meals provided by automatic feeders resulted in better performance of fish fed with higher feed rates than those recommended in the literature for the farming stage, including night meals. Moreover, the high feed rate offered more times per day did not compromise the carcass quality.

\section{REFERENCES}

AGOSTINHO, C.A.; LIMA, S.L.; FORTES, J.V. et al. Dispensador automático de ração. Patente de invento n. 0403612-3, 2004.

ARBELÁEZ-ROJAS, G.A.; FRACALOSSI, D.M.; FIM, J.D.I. Composição corporal de Tambaqui, Colossoma macropomum, e Matrinxã, Brycon cephalus, em sistemas de cultivo intensivo, em igarapé, e semi-intensivo, em viveiros. Rev. Bras. Zootec., v.31, p.10591069, 2002.

AIURA, F.S.; CARVALHO, M.R.B. Composição em ácidos graxos e rendimento de filé de tilápias do Nilo (Oreochromis niloticus) alimentada com dietas contendo tanino. Rev. Port. Ciênc. Vet., v.99, p.93-98, 2004.

BARBOSA, A.C.A.; ALMEIDA, L.D.L.; FONSECA, R.B. Avaliação de diferentes seqüencias de arraçoamento no desenvolvimento de tilápias cultivadas em gaiolas. Natal: Empresa de Pesquisa Agropecuária do Rio Grande do Norte, 2005.

BOYD, C.E. Water quality management for pond fish culture. Amsterdan, The Netherlands: Elsevier Scientific Publishing Company, 1982. $318 p$.

BRASIL, Ministério da Pesca e Aquicultura. Produção pesqueira aquícola: estatística 2008 e 2009. Brasilia, DF: MPA, 2010. (Caderno consolidação dos dados estátiscos). Disponível em:

$<$ http://www.mpa.gov.br/\#publicidade/publicaçõ es>. Acessado em: 12 abr. 2012.
BUREAU, D.P.; HUA, K.; CHO, C.Y. Effect of feeding level on growth and nutrient deposition in rainbow trout (Oncorhynchus mykiss Walbaum) growing from 150 to 600 g. Aquac. Res., v.37, p.1090-1098, 2006.

CARVALHO, E.A.; NUNES, A.J.P. Effects of feeding frequency on feed leanchig loss and grow-out patterns of the white shrimp Litopenaeus vannamei fed under a diurnal feeding regime in pond enclosures. Aquaculture, v.252, p.494-502, 2006.

CHAGAS, E.C.; GOMES, L.C.; MARTINS, J. Desempenho de tambaqui cultivado em tanquesrede, em lago de várzea, sob diferentes taxas de alimentação. Pesqui. Agropecu. Bras., v.40, p.833-835, 2005.

CHO, S.; LIM, Y.; LEE, J.H. Effects of feeding rate and feeding frequency on survival, growth, and body composition of ayu post-larvae Plecoglossus altivelis. J. World Aquacult. Soc., v.34, p.85-91, 2003.

CONTE, L.; SONODA, D.Y.; SHIROTA, R. et al. Productivity and economics of Nile Tilapia Oreochromis niloticus cage culture in South-East Brazil. J. Appl. Aquacult., v.20, p.18-37, 2008.

DU, Z.; LIU, Y.; TIAN, L. et al. The influence of feeding rate on growth, feed efficiency and body composition of juvenile grass carp (Ctenopharyngodon idella). Aquacult. Int., v.14, p.247-257, 2006.

FURUYA, W.M., FURUYA, V. R. B., SOUZA, S. R. Desempenho de tilápias do Nilo (Oreochromis niloticus L.), submetida a dietas fareladas, peletizada e extrusada, na terminação. In: REUNIÃO DA SOCIEDADE BRASILEIRA DE ZOOTECNIA, 34., 1997, Juiz de Fora, MG. Anais... Juiz de Fora: SBZ, 1997. p.230-231. (Resumo).

JEONG, D.; KAYANO, Y.; ODA, T. et al. Influence of feeding regime on fatty acid composition in young red-spotted grouper Epinephelus akaara. Fish. Sci., v.69, p.569-574, 2003.

KANG'OMBE, J.; LIKONGWE, J.S.; EDA, H. Effect of varying dietary energy level on feed intake, feed conversion, whole-body composition and growth of Malasian tilapia, Oreochromis shiranus - Boulenger. Aquac. Res., v.38, p.373380, 2007. 
KIESSLING, A.; PICKOVA, J.; EALES, J.G. et al. Age, ration level, and exercise affect the fatty acid profile of Chinook salmon (Oncorhynchus tshawytscha) muscle differently. Aquaculture, v.243, p.345-356, 2005.

KUBITZA, F. Tilápia: tecnologia e planejamento na produção comercial. Jundiaí: Fernando Kubitza, 2000. 285p.

LEANHARDT, J.H.; URBINATI, E.C. Estudo comparativo do crescimento entre machos de tilápia do nilo, Oreochromis niloticus, sexados e revertidos. Bol. Inst. Pesc., n.25, p.19-26, 1999.

MEURER, F.; HAYASHI, C.; BOSCOLO, W.R. Lípideos na alimentação de alevinos revertidos de Tilápia do Nilo (Oreochromis niloticus, L.). Rev. Bras. Zootec., v.31, p.566-573, 2002.

MIHELAKAKIS, A.; TSOLKAS, C; YOSHIMATSU, T. Optimization of Feeding Rate for Hatchery-Produced Juvenile Gilthed Sea Bream Sparus aurata. J. World Aquacult. Soc., v.33, p.169-175, 2002.

NG, W.; LU, K.; HASHIM, R. Effects of feeding rate on growth, feed utilization and body composition of a tropical catfish. Aquacult. Internat., v.8, p.19-29, 2000.

NOGUEIRA, A C.; RODRIGUES, T. Criação de tilápias em tanques-rede. Salvador, Bahia: Sebrae, 2007.

SOUSA, R.M.R.; AGOSTINHO, C.A.; OLIVEIRA, F.A. et al. Productive performance of Nile tilapia (Oreachromis niloticus) fed at different frequencies and periods with automatic dispenser. Arq. Bras. Med. Vet. Zootec., v.64, p.192-197, 2012.
RICHE, M.; HALEY, D.I.; OETKER, M. Effect of feeding frequency on gastric evacuation and the return of appetite in tilapia Oreachromis niloticus (L.). Aquaculture, v.234, p.657-673, 2004.

RIDHA, M.T. Growth performance of three Nile tilapia strains at two densities Aquac. Res., v.37, p.172-179, 2006.

ROMAGOSA, E.; SCORVO FILHO, J.D.; FRASCÁ-SCORVO, C.M.D. Desempenho de dois lotes de Tilápia-do-Nilo na região do Vale do Ribeira, São Paulo. Pariquera-Açu, SP: Instituto de Pesca, 2000. p.1-30. (Série Relatórios Técnicos, n.7).

WANG, N.; HAYWARD, R.S.; NOLTIE, D.B. Effect of feeding frequency on food consumption, growth, size variation, and feeding pattern of age on hybrid sunfish. Aquaculture, v.165, p.261-267, 1998.

ZARATE, D.D.; LOVELL, R.T.; PAYNE, M. Effects of feeding frequency and rate of stomach evacuation on utilization of dietary free and protein-bound lysine for growth by channel catfish Ictalurus punctatus. Aquacult. Nutr., v.5, p.17-22, 1999.

ZUANON, J.A.S.; ASSANO, M.; FERNANDES, J.B.K. Desempenho de Tricogaster (Trichogaster trichopterus) submetido a diferentes níveis de arraçoamento e Densidades de estocagem. Rev. Bras. Zootec., v.33, p.1639-1645, 2004. 